\title{
A method for the detection of bacteriophages from ocean water
}

\author{
K. Moebus \\ Biologische Anstalt Helgoland (Meeresstation); D-2192 Helgoland, \\ Federal Republic of Germany
}

\begin{abstract}
A method for the isolation of bacteriophages from ocean water is described. It precludes sample storage before starting phage-enrichment cultures and provides for the use of 3 sub-samples enriched with organic nutrients after 1,2 and 3 days of incubation. The method was used with samples collected from $6 \mathrm{~m}$ below the surface at 48 stations between the European continental shelf and the Sargasso Sea. With 213 among 931 bacterial isolates about 250 strains of bacteriophages were detected by two methods of different sensitivity. From 14 samples taken east of the Azores 115 host bacteria have been found versus only 98 from 34 samples collected at westerly stations. The employment of more than one sub-sample per station as well as the use of more sensitive phage-detection procedures was found to be more advantageous the lower the concentration of cultivatable bacteria in a sample.
\end{abstract}

\section{INTRODUCTION}

Among previously described methods for the isolation of bacteriophages from seawater (Spencer, 1955, 1960; Hidaka, 1971, 1977) only that of Hidaka (1977) is suitable for conditions aboard ship. This method involves starting the cultural enrichment of phages before host bacteria are available, so that storage of water samples for a week or even longer is avoided. Hidaka's method, however, neither excludes sample storage for at least one day nor eliminates the need of considerable space in a cooled room to store the treated samples until return. Therefore, it can be employed only during relatively short cruises.

When participating in an 11-week eel biology expedition to the Sargasso Sea with the 370 ton research vessel "Friedrich Heincke" of the Biologische Anstalt Helgoland, I realised the necessity of a method requiring the least possible storage room.

With seawater collected near Helgoland an enrichment culture method precluding sample storage was developed and tested with ocean water during a cruise to the Bay of Biscay in October 1978. After minor adjustments the procedure, which will be described and evaluated in this paper, was used during cruise no. 160 of RV "Friedrich Heincke" lasting from February 12 through April 26, 1979. 


\section{MATERIALS AND METHODS}

\section{Media}

Seawater agar (SWA), soft seawater agar (sSWA) and seawater broth (SWB/5) were prepared with $75 \%$ aged North Sea water and $25 \%$ distilled water. SWA and sSWA contained $5 \mathrm{~g}$ peptone (Difco), $1 \mathrm{~g}$ yeast extract (Difco), and $0.1 \mathrm{~g} \mathrm{FePO}$, per liter but differed in their agar (Difco) content which was $1.5 \%$ and $0.6 \%$, respectively. SWB $/ 5$ was prepared with $1 \mathrm{~g}$ peptone (Difco), $0.2 \mathrm{~g}$ yeast extract (Difco), and $0.1 \mathrm{~g} \mathrm{FePO}_{4}$ per liter. The $\mathrm{pH}$ of these media was about 7.6 after autoclaving for $20 \mathrm{~min}$ at $121^{\circ} \mathrm{C}$.

Concentrated peptone-yeast extract solution $(25 \times \mathrm{PY})$ containing $125 \mathrm{~g}$ peptone (Difco) and $25 \mathrm{~g}$ yeast extract (Difco) per liter, and a $3 \%$ solution of Difco beef extract (BES) were prepared with distilled water only.

The media were dispensed into screw-cap bottles or tubes in amounts corresponding to the expected demand per seawater sample to be investigated. In addition, 1400 Petri dishes containing $20 \mathrm{ml}$ SWA each were prepared and sealed in sterile plastic bags immediately after cooling to room temperature. All media were stored in the dark at $5^{\circ} \mathrm{C}$.

\section{Sampling of seawater}

Seawater samples were collected aseptically from $6 \mathrm{~m}$ below the surface $(3 \mathrm{~m}$ below the keel) with a sampler holding 2 bottles of 5- and 1-1 capacity, which were connected to a common inlet tube. Sampling generally took less than $5 \mathrm{~min}$.

\section{Treatment of seawater samples}

All samples were treated immediately after collection to enrich bacteriophages and to cultivate bacteria.

\section{Enrichment of bacteriophages}

Three sub-samples of 1.51 seawater were dispensed into sterile bottles of 2-1 capacity. At zero time $12 \mathrm{ml}$ of $25 \times \mathrm{PY}$ were added to Sub-sample 1 resulting in a concentration of peptone and yeast extract corresponding to that in SWB $/ 5$. Sub-samples 2 and 3 received the same amounts of nutrients only after 24 and $48 \mathrm{~h}$ of incubation, respectively (pre-incubated sub-samples). Incubation was normally performed in still culture at $20^{\circ}$ to $21^{\circ} \mathrm{C}$, but for several weeks at ambient temperature $\left(23^{\circ}\right.$ to $\left.26^{\circ} \mathrm{C}\right)$ due to a breakdown of the cooling equipment.

From each sub-sample aliquots of $10 \mathrm{ml}$ were taken 1,2 and 3 days after the addition of $25 \times \mathrm{PY}$ and centrifuged for $20 \mathrm{~min}$ at about $2000 \mathrm{rpm}$ to remove most of the profusely grown bacteria. Centrifugation was performed on a table suspended by a cardan joint. Finally the supernatants were filtered through $0.15-\mu \mathrm{m}$ cellulose-nitrate filters (Sartorius, Göttingen) previously washed with $1 \mathrm{ml}$ BES to prevent phage adsorption.

To handle as many as 8 supernatants at the same time, the following procedure was used: Filters, $25 \mathrm{~mm}$ in diameter, were mounted in polycarbonate filter holders (Sartorius) and autoclaved. Before use the outlets of the filter holders were pressed into holes drilled in the polycarbonate lid of an autoclaved box and the bodies of disposable 
syringes attached to the filter holders. The box itself was affixed on the table by means of double-sided sticky tape. Then BES was slowly passed through the filters and the supernatants poured into the syringe bodies. The filter-syringe assemblies were removed from the box one after the other and the supernatants filtered directly into sterile plastic screw-cap tubes to be stored at $5^{\circ} \mathrm{C}$.

In this way 9 preparations were obtained from each seawater sample to be checked for the presence of bacteriophages.

\section{Cultivation of bacteria}

Bacterial colonies were grown on SWA inoculated with $0.1 \mathrm{ml}$ per plate and incubated for 7 days at $25^{\circ} \mathrm{C}$. Before use the SWA plates were kept at room temperature (usually above $20^{\circ} \mathrm{C}$ ) for 2 to 3 days to attain the desired degree of dryness and to show possible contamination as well.

Since the number of colony-forming units (CFU) is generally very low in ocean water the following procedure was employed with all seawater samples investigated to concentrate bacteria before cultivation. Using sterilized equipment only, seawater was drawn by vacuum from a graduated cylinder into a filter apparatus through tubing running from the tightly fitting lid of the filter funnel to the bottom of the cylinder. The latter was closed with a lid bearing a hole for the tubing. Nuclepore filters of $47 \mathrm{~mm}$ diameter and $0.2 \mu \mathrm{m}$ pore size were used to collect suspended material.

The greater part of the retained bacteria was washed off the filter by repeated squirting of the same 2 to $3 \mathrm{ml}$ of seawater with a pipette. Finally, the suspension was transferred to a tube and spread on series of 5 SWA plates each undiluted as well as after $2-, 5-$, and 10-fold dilution.

The filter was placed on SWA, examined under a dissecting microscope, and incubated for 7 days at $25^{\circ} \mathrm{C}$. The amount of seawater filtered and the time needed for this process were recorded.

From a few samples only, untreated seawater was also spread on SWA. Since the number of colonies was always very low this method was abandoned. However, with all but 3 samples investigated the number of CFU was determined in the 2 pre-incubated sub-samples just prior to the addition of $25 \times \mathrm{PY}$.

After incubation, as many seemingly different colonies (or parts thereof) as possible were picked from the plates. Preferentially the colonies were selected from SWA inoculated with the concentrate of particulate matter. Since, however, often less than the minimum number of 30 different colonies could be found on these plates, for most of the water samples colonies were also picked from SWA inoculated with material of the preincubated sub-samples.

The selected microbes were transferred into $2 \mathrm{ml} \mathrm{SWB} / 5$ and incubated for 2 days at $25^{\circ} \mathrm{C}$. These cultures then were streaked on SWA slants which, after incubation for another 2 days at the same temperature, were stored at $5^{\circ} \mathrm{C}$.

\section{Detection of bacteriophages}

After our return to Helgoland each series of 9 preparations produced from the phage-enrichment cultures was tested for the presence of bacteriophages with the bacteria isolated from the respective sample of seawater. Two methods were used, each 
employing plates with $10 \mathrm{ml}$ of SWA as bottom layer and $2.5 \mathrm{ml}$ of sSWA as top layer, the latter seeded with bacteria.

At first a common spot test was performed with small amounts of the preparations transferred onto the top layers by means of a multi-point inoculator. This test revealed bacteriophages only if they were present in fairly large numbers. To detect rare phages, another series of experiments was performed employing so-called ring holders.

The ring holders were produced in the institute's workshop from Lexan ${ }^{\circledR}$ sheet ( $3 \mathrm{~mm}$ thick) and Makrolon ${ }^{8}$ rings ( $8 \mathrm{~mm}$ high, $15 \mathrm{~mm}$ outer diameter), the latter glued into holes drilled in the sheet. They can be sterilized by autoclaving $\left(20 \mathrm{~min}\right.$ at $\left.121^{\circ} \mathrm{C}\right)$.

Double-layer plates were poured as in the afore-mentioned test. This time, however, only those bacteria were used which had not been found to be suitable hosts during the first test series. In each plate a ring holder was pressed right through both agar layers thereby forming 9 wells, into which $0.1 \mathrm{ml}$ of the preparations was placed. The plates were incubated overnight at $25^{\circ} \mathrm{C}$. After incubation some liquid was withdrawn from the wells to be spot-tested on freshly poured top layers seeded with the respective bacteria. This procedure was necessary to obtain clear-cut results which had not been produced with the plates containing the ring holders. With the ring holders in place or already removed, only rarely were unequivocal indications of lysis observed, whereas with the liquid from many unsuspicious wells strong lytic action was found after re-testing. Each lysis-positive spot was removed from the plate and transferred into $2.5 \mathrm{ml}$ of SWB $/ 5$ to be stored as eluate in the refrigerator.

\section{Isolation and purification of bacteriophages}

To isolate the detected phages, serial dilutions of either the preparations produced from sub-samples or the eluates mentioned in the last paragraph were used to pour double-layer plates with the respective host bacteria. Generally, with each strain of host bacteria only one representative preparation or eluate per sub-sample was titrated. Only if the presence of different phages was indicated by the results of the spot tests described above was more than one preparation or eluate used. After incubation at $25^{\circ} \mathrm{C}$ single plaques were isolated from the plates and eluted in $1 \mathrm{ml}$ of seawater each. These eluates again were titrated with the respective host bacteria to produce another generation of single plaques. To purify the isolated phages, this procedure was repeated at least three times.

During the process of isolation and purification, doublets of phages and host bacteria derived from the same sample of seawater (intrasample doublets) were eliminated. The designation of bacteriophages as doublets was generally based on the similarity of appearance of the plaques they produced with a bacterial host. Concerning host bacteria, doublets were detected by spot testing all remaining isolates of bacteriophages on top layers seeded with the host bacteria isolated from the same seawater sample. This host-phage cross infection test was performed after 3 consecutive isolations of single plaques.

Finally high-titre phage stocks were prepared by eluting top layers showing approximately confluent lysis with $10 \mathrm{ml}$ of $\mathrm{SWB} / 5$ for $1 \mathrm{~h}$ at room temperature, followed by centrifuging the eluates to remove debris and filtration of the supernatants through 0.15 $\mu \mathrm{m}$ filters as described above. These cell-free lysates were stored in the refrigerator. 
Bacteriophages from ocean water

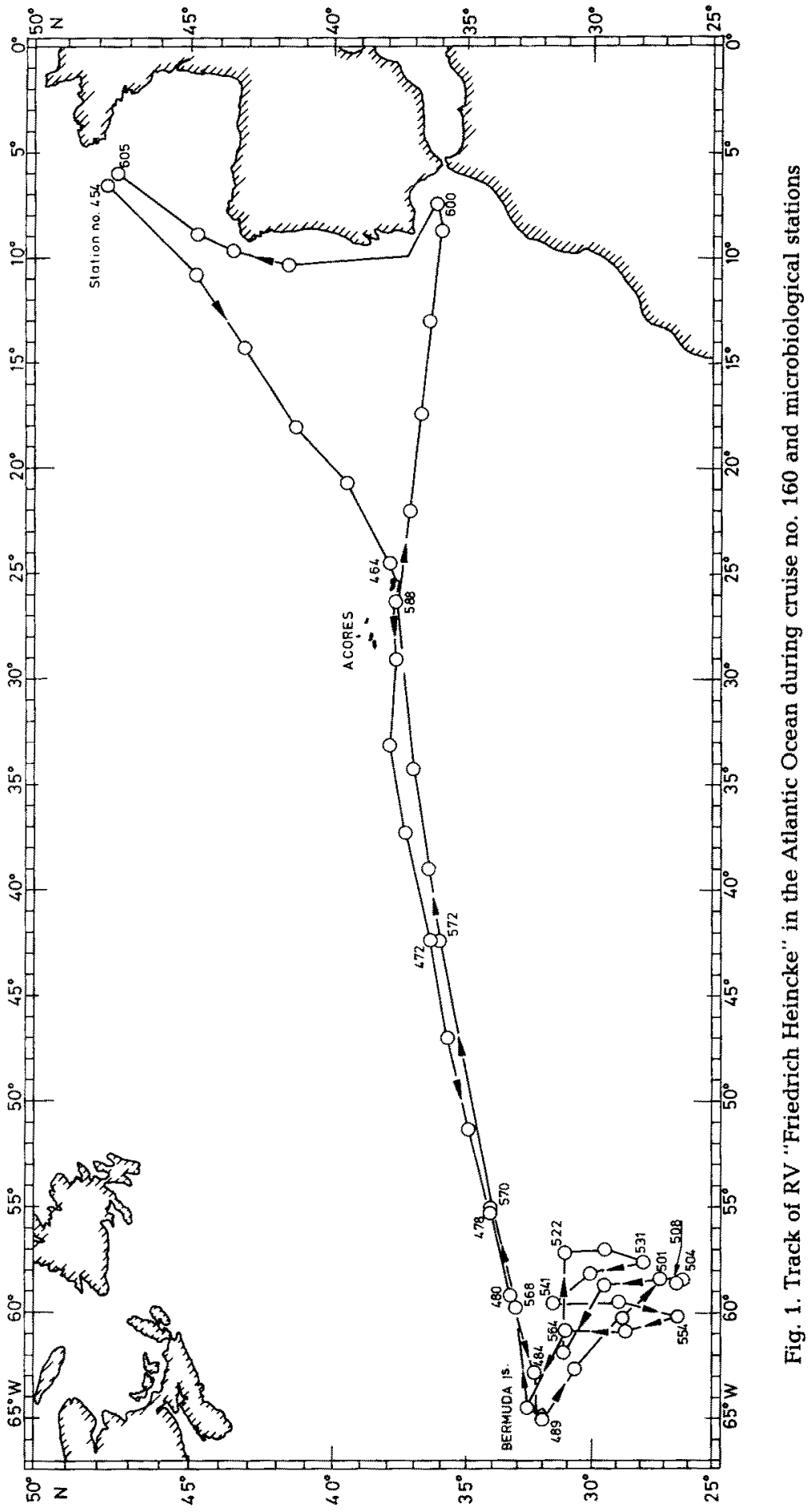


K. Moebus

Table 1. Physical data of microbiological stations

\begin{tabular}{|c|c|c|c|c|c|c|c|}
\hline \multirow{2}{*}{$\begin{array}{c}\text { Station } \\
\text { no. }\end{array}$} & \multicolumn{2}{|c|}{ Position } & \multirow[t]{2}{*}{ Date } & \multicolumn{2}{|c|}{ Time of sampling } & \multicolumn{2}{|c|}{ Temperature $\left({ }^{\circ} \mathrm{C}\right)$} \\
\hline & Latitude & Longitude & & Ship & GMT & Water & Air \\
\hline 454 & $47^{\circ} 43^{\prime} \mathrm{N}$ & $06^{\circ} 38^{\prime} \mathrm{W}$ & February 15 & $07: 30$ & $=$ & 11.5 & 3.0 \\
\hline 456 & $44^{\circ} 45^{\prime} \mathrm{N}$ & $10^{\circ} 55^{\prime} \mathrm{W}$ & 16 & $08: 20$ & $=$ & 14.5 & 8.0 \\
\hline 458 & $43^{\circ} 12^{\prime} \mathrm{N}$ & $14^{\circ} 17^{\prime} \mathrm{W}$ & 17 & $09: 10$ & $=$ & 15.0 & 13.0 \\
\hline 460 & $41^{\circ} 21^{\prime} \mathrm{N}$ & $18^{\circ} 04^{\prime} \mathrm{W}$ & 18 & $09: 30$ & $=$ & 15.0 & 12.0 \\
\hline 462 & $39^{\circ} 39^{\prime} \mathrm{N}$ & $21^{\circ} 48^{\prime} \mathrm{W}$ & 19 & $10: 05$ & $=$ & 15.7 & 16.0 \\
\hline 464 & $38^{\circ} 00^{\prime} \mathrm{N}$ & $24^{\circ} 38^{\prime} \mathrm{W}$ & 20 & $10: 35$ & $=$ & 16.2 & 13.0 \\
\hline 465 & $37^{\circ} 49^{\prime} \mathrm{N}$ & $29^{\circ} 03^{\prime} \mathrm{W}$ & 24 & $08: 00$ & $+2 \mathrm{~h}$ & 16.1 & 15.0 \\
\hline 469 & $37^{\circ} 58^{\prime} \mathrm{N}$ & $33^{\circ} 17^{\prime} \mathrm{W}$ & 25 & $08: 15$ & $+2 h$ & 16.3 & 17.0 \\
\hline 471 & $37^{\circ} 20^{\prime} \mathrm{N}$ & $37^{\circ} 21^{\prime} \mathrm{W}$ & 26 & $08: 20$ & $+2 \mathrm{~h}$ & - & 17.0 \\
\hline 472 & $36^{\circ} 33^{\prime} \mathrm{N}$ & $42^{\circ} 23^{\prime} \mathrm{W}$ & 27 & $09: 20$ & $+2 \mathrm{~h}$ & 17.6 & 18.5 \\
\hline 474 & $35^{\circ} 43^{\prime} \mathrm{N}$ & $47^{\circ} 05^{\prime} \mathrm{W}$ & 28 & $08: 20$ & $+3 h$ & 18.4 & 18.0 \\
\hline 476 & $34^{\circ} 52^{\prime} \mathrm{N}$ & $51^{\circ} 31^{\prime} \mathrm{W}$ & March 1 & $08: 20$ & $+3 \mathrm{~h}$ & - & 18.0 \\
\hline 478 & $34^{\circ} 01^{\prime} \mathrm{N}$ & $55^{\circ} 19^{\prime} \mathrm{W}$ & 2 & $09: 20$ & $+3 h$ & 18.7 & 17.0 \\
\hline 480 & $33^{\circ} 13^{\prime} \mathrm{N}$ & $59^{\circ} 20^{\prime} \mathrm{W}$ & 3 & $09: 15$ & $+3 \mathrm{~h}$ & 19.6 & 18.0 \\
\hline 484 & $32^{\circ} 34^{\prime} \mathrm{N}$ & $62^{\circ} 57^{\prime} \mathrm{W}$ & 4 & $09: 15$ & $+3 \mathrm{~h}$ & 20.3 & 17.0 \\
\hline 489 & $31^{\circ} 58^{\prime} \mathrm{N}$ & $65^{\circ} 11^{\prime} \mathrm{W}$ & 8 & $09: 30$ & $+4 \mathrm{~h}$ & 20.2 & 22.0 \\
\hline 492 & $30^{\circ} 40^{\prime} \mathrm{N}$ & $62^{\circ} 45^{\prime} \mathrm{W}$ & 9 & $09: 20$ & $+4 h$ & 21.0 & 21.0 \\
\hline 497 & $28^{\circ} 47^{\prime} \mathrm{N}$ & $60^{\circ} 21^{\prime} \mathrm{W}$ & 10 & $09: 30$ & $+4 \mathrm{~h}$ & 21.0 & 20.0 \\
\hline 501 & $27^{\circ} 07^{\prime} \mathrm{N}$ & $58^{\circ} 33^{\prime} \mathrm{W}$ & 11 & $07: 35$ & $+4 \mathrm{~h}$ & 22.2 & 22.0 \\
\hline 504 & $26^{\circ} 06^{\prime} \mathrm{N}$ & $58^{\circ} 35^{\prime} \mathrm{W}$ & 12 & $07: 20$ & $+4 \mathrm{~h}$ & 22.3 & 22.0 \\
\hline 508 & $26^{\circ} 25^{\prime} \mathrm{N}$ & $58^{\circ} 47^{\prime} \mathrm{W}$ & 13 & $07: 35$ & $+4 \mathrm{~h}$ & 23.5 & 23.0 \\
\hline 513 & $29^{\circ} 37^{\prime} \mathrm{N}$ & $58^{\circ} 53^{\prime} \mathrm{W}$ & 14 & $07: 30$ & $+4 h$ & 20.2 & 19.0 \\
\hline 518 & $31^{\circ} 12^{\prime} \mathrm{N}$ & $62^{\circ} 01^{\prime} \mathrm{W}$ & 15 & $07: 30$ & $+4 \mathrm{~h}$ & 21.2 & 21.0 \\
\hline 522 & $31^{\circ} 04^{\prime} \mathrm{N}$ & $57^{\circ} 18^{\prime} \mathrm{W}$ & 20 & $08: 05$ & $+4 \mathrm{~h}$ & 19.2 & 17,2 \\
\hline 526 & $29^{\circ} 36^{\prime} \mathrm{N}$ & $57^{\circ} 05^{\prime} \mathrm{W}$ & 21 & $08: 15$ & $+4 h$ & 20.7 & 18.0 \\
\hline 531 & $27^{\circ} 56^{\prime} \mathrm{N}$ & $57^{\circ} 44^{\prime} \mathrm{W}$ & 22 & $08: 05$ & $+4 \mathrm{~h}$ & 21.3 & 17.0 \\
\hline 536 & $30^{\circ} 00^{\prime} \mathrm{N}$ & $58^{\circ} 20^{\prime} \mathrm{W}$ & 23 & 09:00 & $+4 \mathrm{~h}$ & 21.1 & 18.0 \\
\hline 541 & $31^{\circ} 30^{\prime} \mathrm{N}$ & $59^{\circ} 40^{\prime} \mathrm{W}$ & 24 & $08: 55$ & $+4 \mathrm{~h}$ & 20.1 & 19.0 \\
\hline 547 & $28^{\circ} 50^{\prime} \mathrm{N}$ & $59^{\circ} 38^{\prime} \mathrm{W}$ & 25 & $08: 45$ & $+4 \mathrm{~h}$ & 21.8 & 20.0 \\
\hline 554 & $26^{\circ} 31^{\prime} \mathrm{N}$ & $60^{\circ} 14^{\prime} \mathrm{W}$ & 26 & $08: 50$ & $+4 \mathrm{~h}$ & 21.8 & 22.0 \\
\hline 559 & $28^{\circ} 30^{\prime} \mathrm{N}$ & $61^{\circ} 00^{\prime} \mathrm{W}$ & 27 & $09: 05$ & $+4 \mathrm{~h}$ & 20.9 & 19.5 \\
\hline 564 & $30^{\circ} 30^{\prime} \mathrm{N}$ & $61^{\circ} 00^{\prime} \mathrm{W}$ & 28 & $08: 50$ & $+4 \mathrm{~h}$ & 20.0 & 19.0 \\
\hline 565 & $32^{\circ} 20^{\prime} \mathrm{N}$ & $64^{\circ} 38^{\prime} \mathrm{W}$ & 31 & $08: 15$ & $+4 \mathrm{~h}$ & 18.7 & 19.0 \\
\hline 568 & $33^{\circ} 03^{\prime} \mathrm{N}$ & $59^{\circ} 59^{\prime} \mathrm{W}$ & April 1 & $09: 20$ & $+3 \mathrm{~h}$ & 19.3 & 19.0 \\
\hline 570 & $34^{\circ} 01^{\prime} \mathrm{N}$ & $55^{\circ} 19^{\prime} W$ & 2 & $09: 30$ & $+3 \mathrm{~h}$ & 18.5 & 18.0 \\
\hline 572 & $36^{\circ} 03^{\prime} \mathrm{N}$ & $42^{\circ} 28^{\prime} W$ & 5 & $11: 00$ & $+2 \mathrm{~h}$ & 17.7 & 15.0 \\
\hline 576 & $36^{\circ} 26^{\prime} \mathrm{N}$ & $39^{\circ} 04^{\prime} \mathrm{W}$ & 6 & $08: 20$ & $+2 h$ & 17.3 & 17.0 \\
\hline 581 & $37^{\circ} 03^{\prime} \mathrm{N}$ & $34^{\circ} 21^{\prime} \mathrm{W}$ & 7 & $08: 25$ & $+2 \mathrm{~h}$ & 17.7 & 17.0 \\
\hline 588 & $37^{\circ} 46^{\prime} \mathrm{N}$ & $26^{\circ} 22^{\prime} \mathrm{W}$ & 9 & $08: 15$ & $+2 \mathrm{~h}$ & 16.5 & 13.0 \\
\hline 590 & $37^{\circ} 20^{\prime} \mathrm{N}$ & $22^{\circ} 02^{\prime} \mathrm{W}$ & 12 & $08: 50$ & $=$ & 16.3 & 13.5 \\
\hline 593 & $36^{\circ} 51^{\prime} \mathrm{N}$ & $17^{\circ} 25^{\prime} \mathrm{W}$ & 13 & $08: 50$ & $=$ & 16.6 & 13.5 \\
\hline 596 & $36^{\circ} 30^{\prime} \mathrm{N}$ & $13^{\circ} 00^{\prime} \mathrm{W}$ & 14 & $08: 45$ & $=$ & 16.2 & 15.5 \\
\hline 598 & $36^{\circ} 07^{\prime} \mathrm{N}$ & $08^{\circ} 43^{\prime} \mathrm{W}$ & 15 & $08: 50$ & $=$ & 16.6 & 15.0 \\
\hline 600 & $36^{\circ} 20^{\prime} \mathrm{N}$ & $07^{\circ} 28^{\prime} \mathrm{W}$ & 16 & $08: 45$ & $=$ & 17.1 & 13.5 \\
\hline 601 & $41^{\circ} 35^{\prime} \mathrm{N}$ & $10^{\circ} 20^{\prime} \mathrm{W}$ & 21 & $08: 00$ & $-1 \mathrm{~h}$ & 14.6 & 12.0 \\
\hline 602 & $43^{\circ} 37^{\prime} \mathrm{N}$ & $09^{\circ} 34^{\prime} \mathrm{W}$ & 21 & $20: 00$ & $-1 \mathrm{~h}$ & 13.7 & 14.0 \\
\hline 603 & $44^{\circ} 47^{\prime} \mathrm{N}$ & $08^{\circ} 50^{\prime} \mathrm{W}$ & 22 & $08: 00$ & $-1 \mathrm{~h}$ & 13.9 & 13.0 \\
\hline 605 & $47^{\circ} 32^{\prime} \mathrm{N}$ & $06^{\circ} 17^{\circ} \mathrm{W}$ & 23 & $08: 00$ & $-1 \mathrm{~h}$ & 12.8 & 13.0 \\
\hline
\end{tabular}




\section{RESULTS}

Seawater samples were collected at the 48 stations shown in Figure 1. Additional information is compiled in Table 1. The depth at the sampling sites was between several hundred and several thousand metres with the following exception: $120 \mathrm{~m}$ and $144 \mathrm{~m}$ at Station nos. 454 and 605, respectively (Bay of Biscay), $60 \mathrm{~m}$ at Station no. 489 (Plantagenet Bank, southwest of Bermuda) and $12 \mathrm{~m}$ at Station no. 565 (about $800 \mathrm{~m}$ off St. George's, Bermuda).

For the bacteria the main purpose of the experiments performed was to isolate a reasonably large number of different bacterial strains but not necessarily to collect exact data on the bacterial content of the seawater samples. Therefore, only rough estimates of the numbers of CFU were obtained (Table 2). They are based on the numbers of $\mathrm{CFU} \mathrm{ml}{ }^{-1}$ found with the suspensions of concentrated particulate material and the estimated numbers of colonies grown on the filters used in the concentration procedure, taking into account the respective concentration factor. Table 2 also presents the numbers of CFU ml ${ }^{-1}$ determined for sub-samples pre-incubated without organic nutrients added. In most cases the results obtained with related sub-samples after $24 \mathrm{~h}$ of preincubation agree fairly well. Mostly they are also reasonably correlated with the rough estimates of CFU present in the seawater at collection time, especially when these are very low. Therefore, it is supposed that the rough estimates of the CFU content of the samples presented in Table 2 are not unrealistic. However, they may be somewhat too low since Nuclepore ${ }^{\circledR}$ filters of $0.2-\mu \mathrm{m}$ pore size do not retain all bacteria.

At the end of the cruise 1382 microbial islates had been collected, 451 of which did not survive until they could be used to detect bacteriophages in the preparations made from phage-enrichment cultures. Among the remaining 931 isolates, 213 were found to be suitable hosts for bacteriophages, including 36 doublets.

The distribution of host bacteria among all microbial strains isolated from the 48 seawater samples is shown in Figure 2 . With $70 \%$ of the hosts, bacteriophages were detected during the first test series employing the multi-point inoculator (squares in Fig. 2), whereas with the remaining host bacteria (circles in Fig. 2) phages could be found only in the second, more sensitive test series using the ring holders. As revealed during the isolation procedure, bacteriophages detected by means of the multi-point inoculator were present in the preparations at numbers ranging from about $10 \mathrm{ml}^{-1}$ to $5 \times 10^{7} \mathrm{ml}^{-1}$.

With $40 \%$ of the host bacteria, bacteriophages were found in preparations of all 3 related sub-samples, whereas with about $35 \%$ of the hosts, bacteriophages were detected in preparations of only one of the 3 sub-samples. Table 3 presents these findings in detail. In Table 4 the numbers of host bacteria are given with which bacteriophages would have been found with 1,2 or 3 sub-samples on the one hand and, on the other hand, if preparations would have been produced only after 1,2,1 and 2, or 2 and 3 days of incubation after nutrient enrichment of the sub-samples.

Generally the same type (or types) of bacteriophage was found in the preparations made successively from a sub-sample. (Often, however, phages were detected with only one preparation of a sub-sample.) Mostly this also holds true in regard to the preparations derived from the 3 related sub-samples, but it was not uncommon to detect different phages from related subsamples with the same bacterial host. In sum, more than 250 strains of bacteriophages were isolated and purified, including some mutants selected during the process of purification. 


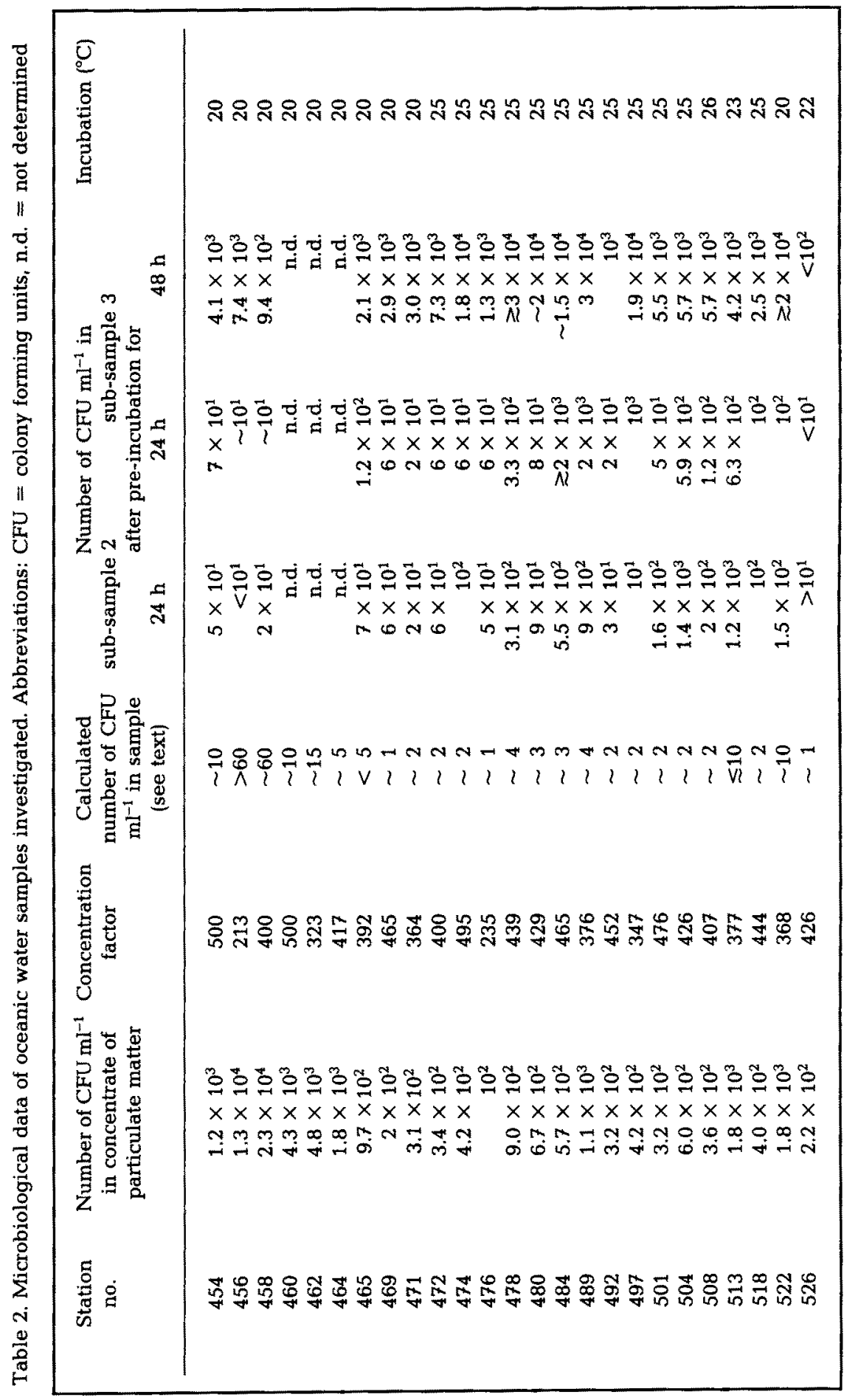




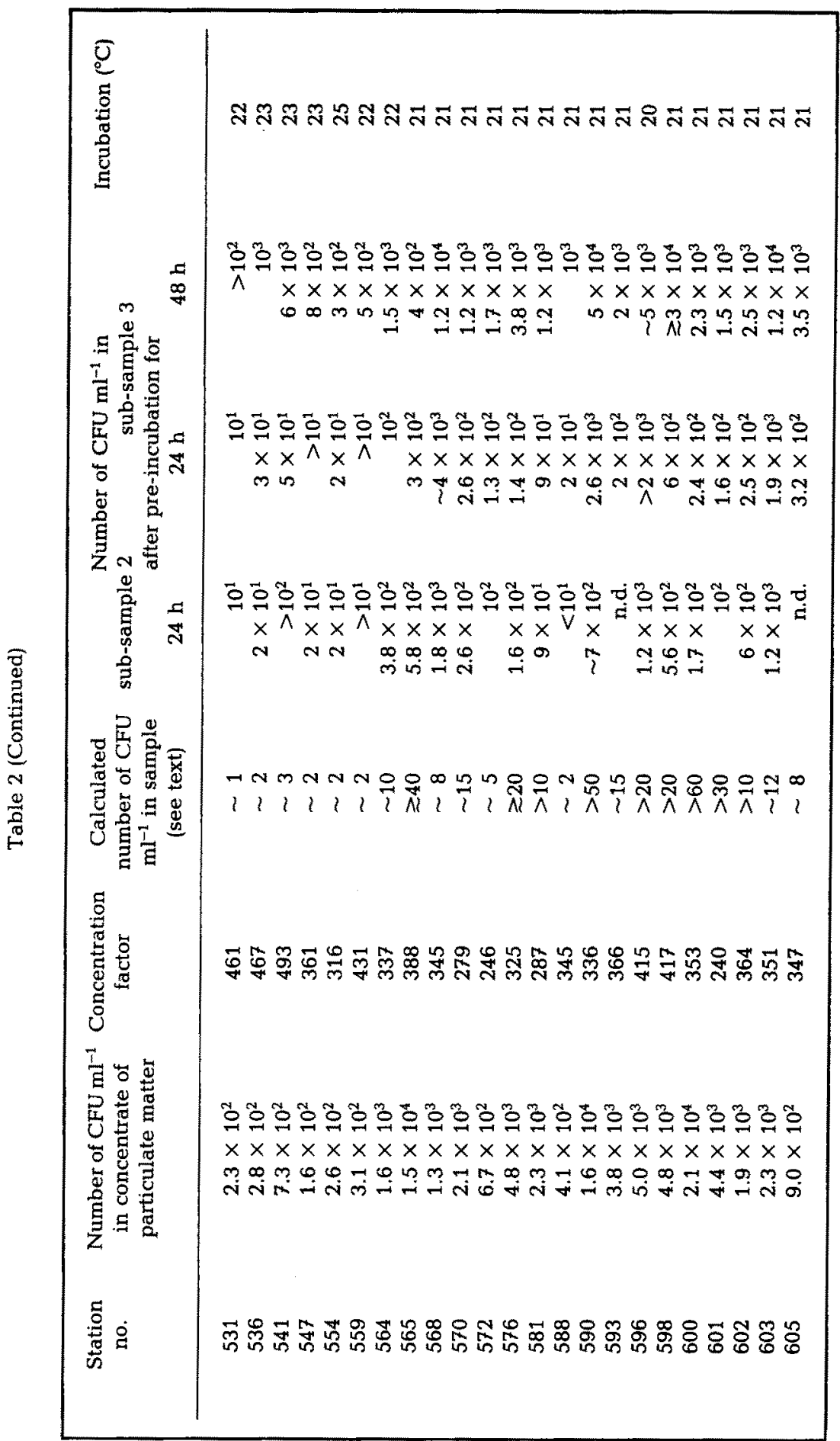




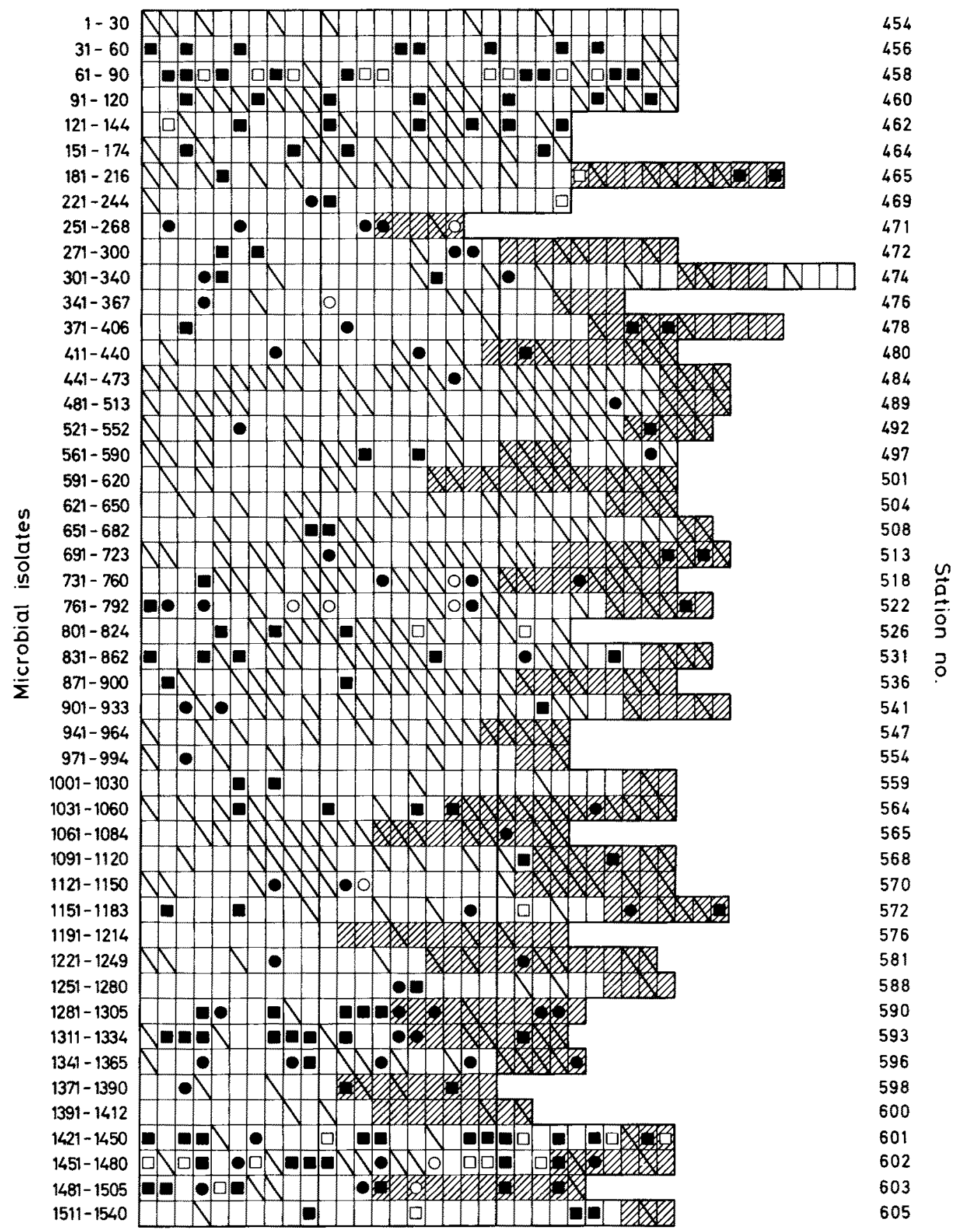

Fig. 2. Microbial isolates as collected from 48 Atlantic Ocean water samples. Plain areas: isolates derived from concentrate of particulate matter; dashed areas: isolates obtained from pre-incubated sub-samples; bars indicate lost isolates; $\mathbf{m}+\square$ : host bacteria found during phage-detection tests employing multi-point inoculator; $\bullet+O$ : host bacteria detected in tests using ring holders; open symbols: bacterial doublets among isolates of respective sample 
Table 3. Numbers of host bacteria isolated from 48 oceanic water samples in relation to the detection of bacteriophages from 3 related sub-samples per sample by two phage-detection procedures

\begin{tabular}{|c|c|c|c|c|c|c|}
\hline \multirow[t]{2}{*}{ In sub-samples } & \multicolumn{4}{|c|}{$\begin{array}{l}\text { Host bacteria indicating the presence of } \\
\text { bacteriophages in test series employing }\end{array}$} & \multirow{2}{*}{\multicolumn{2}{|c|}{ Sum }} \\
\hline & multi-p & oint inoculator & $\operatorname{rin}$ & holders & & \\
\hline 1 to 3 & 71 & $(48.0 \%)$ & 15 & $(23.1 \%)$ & 86 & $(40.4 \%)$ \\
\hline 1 only & 18 & $(12.2 \%)$ & 16 & $(24.6 \%)$ & 34 & $(16.0 \%)$ \\
\hline $1+2$ & 17 & $(11.5 \%)$ & 7 & $(10.8 \%)$ & 24 & $(11.3 \%)$ \\
\hline $1+3$ & 7 & $(4.7 \%)$ & 6 & $(9.2 \%)$ & 13 & $(6.1 \%)$ \\
\hline 2 only & 8 & $(5.4 \%)$ & 5 & $(7.7 \%)$ & 13 & $(6.1 \%)$ \\
\hline $2+3$ & 10 & $(6.7 \%)$ & 5 & $(7.7 \%)$ & 15 & $(7.0 \%)$ \\
\hline \multirow[t]{2}{*}{3 only } & 17 & $(11.5 \%)$ & 11 & $(16.9 \%)$ & 28 & $(13.1 \%)$ \\
\hline & 148 & $(100 \%)$ & 65 & $(100 \%)$ & 213 & $(100 \%)$ \\
\hline
\end{tabular}

Table 4. Numbers of host bacteria isolated from 48 oceanic water samples in relation to the detection of bacteriophages with preparations derived from related sub-samples. Their dependence upon number of sub-samples per sample and schedule of preparation production. 213 host bacteria $=100 \%$

\begin{tabular}{|crcc|}
\hline $\begin{array}{c}\text { Sub-samples } \\
\text { incubated } \\
\text { (days) }\end{array}$ & \multicolumn{3}{c}{$\begin{array}{c}\text { Host bacteria indicating the presence of bacteriophages } \\
\text { in preparations made from } \\
\text { Sub-samples 1 and 2 }\end{array}$} \\
\hline 1 & Sub-sample 1 only-samples 1 to 3 \\
\hline 2 & $144(67.6 \%)$ & $123(57.8 \%)$ & $149(70.0 \%)$ \\
$1+2$ & $149(70.0 \%)$ & $168(78.9 \%)$ & $194(91.1 \%)$ \\
$2+3$ & $152(71.4 \%)$ & $175(82.2 \%)$ & $202(94.9 \%)$ \\
& $179(84.0 \%)$ & $206(96.7 \%)$ \\
\hline
\end{tabular}

Table 5. Numbers of collected and lost microbial isolates in relation to source and pigment production

\begin{tabular}{|lcccc|}
\hline \multicolumn{1}{|c}{ Source } & $\begin{array}{c}\text { Microbial } \\
\text { isolates } \\
\text { collected }\end{array}$ & $\begin{array}{c}\text { Coloured } \\
\text { isolates } \\
\text { collected }\end{array}$ & $\begin{array}{c}\text { Microbial } \\
\text { isolates } \\
\text { lost }\end{array}$ & $\begin{array}{c}\text { Coloured } \\
\text { isolates } \\
\text { lost }\end{array}$ \\
\hline $\begin{array}{l}\text { Particulate matter con- } \\
\text { centrate of sea water }\end{array}$ & 1083 & 276 & 310 & 114 \\
$\begin{array}{l}\text { Pre-incubated sub- } \\
\text { samples 2 and 3 }\end{array}$ & $(100 \%)$ & $(100 \%)$ & $(28.6 \%)$ & $(41.4 \%)$ \\
\hline
\end{tabular}

Finally, the loss of a very great number of microbial isolates should be considered. When the isolates were incubated in $2 \mathrm{ml}$ of SWB/5 each, poor growth was observed in some cases. The same was found with several isolates when incubated on SWA slants. Later on, many strains ceased to grow during consecutive cultivations. Such observations are also not unusual with bacteria from the North Sea. However, with the remaining 
isolates the period of time they remain vital on SWA slants, which is obviously independent of their ability to grow on this medium, generally seems to be shorter than that observed with the majority of bacteria isolated from North Sea water.

The source of the isolates and their ability to form pigments were observed to affect survival. The data presented in Table 5 show that the portion of lost microbial strains derived from pre-incubated sub-samples was about twice that of isolates picked from SWA inoculated soon after collection of the seawater samples. From both sources disproportionately large numbers of coloured isolates were lost.

\section{DISCUSSION}

ZoBell (1946, p. 83) wrote: "Since bacteriophage is generally found associated with large numbers of rapidly multiplying bacteria, it is very doubtful if the sparse bacterial population characteristic of the open ocean is conducive to the development or activity of bacteriophage." Since then, the occurrence of bacteriophages in ocean water has been documented only twice. Hidaka (1977) reported the isolation of bacteriophages from samples collected in the southwestern part of the Pacific Ocean from depths between 1 and $200 \mathrm{~m}$. Among 576 bacterial strains 72 were found to be phage-sensitive, and the 72 bacteriophages isolated with these hosts could be ascribed to 7 groups according to their host range. Johnson \& Sieburth (1978) observed bacteriophage particles by transmission electron microscopy in preparations obtained by concentrating open ocean water $2-5000$ times.

Chaina (1965) isolated 629 bacterial strains from Indian Ocean water and sediment; 10 of these were susceptible to bacteriophages, but their actual source was not given.

This scarcity of information, at least in part, seems to be due to a general lack of interest in marine bacteriophages as documented by the small overall number of publications dealing with these viruses during the last 3 decades. Admittedly the rareness of phage particles in typical marine environments poses technical problems which sometimes can be overcome only by considerable effort as demonstrated by the present paper. However, the occurrence of marine bacteriophages indicates that these viruses are an integral part of their environment and, therefore, should not be neglected.

The method reported in this paper is specifically adapted to the needs and limitations aboard ship during long-range cruises as well as to the investigation of seawater containing extremely low numbers of bacteria which can be grown on presently known media. Obviously it can be simplified to some degree. According to the observations compiled in Table 4, at least the preparations produced from the phage-enrichment cultures after 1 day of incubation could be omitted since only about $4 \%$ of the host bacteria would have been missed provided that from 3 sub-samples preparations were made after 2 and 3 days of incubation. The use of several sub-samples is without doubt preferable to that of only one sample.

As can be seen in Figure 2, many more host bacteria were found among the isolates obtained from seawater samples collected at stations east of the Azores (Station nos. 454 to 462 and 590 to 605) than from samples taken at stations west of this archipelago, although approximately the same number of isolates per station was obtained in both regions. The actual numbers of phage-sensitive isolates are 115 for the 14 eastern stations versus 98 for the 34 western stations. This coincides with a difference in the 
densities of bacterial populations observed with seawater samples collected east and west of the Azores (Table 2), the first ones generally characterized by higher concentrations of CFU. As compiled from the findings obtained during the phage-detection tests, bacteriophages were found from Sub-samples 2 and/or 3 alone with only $20(=17.4 \%)$ among 115 "eastern" host bacteria but with 36 (=37\%) among the 98 "western" hosts. This indicates that the use of several sub-samples is more advantageous the poorer the bacterial population of a seawater sample.

It is unknown, however, to what extent pre-incubation of sub-samples without organic nutrients added is beneficial as compared with the use of the same number of sub-samples all enriched at zero time. The employment of pre-incubation is based on the assumption that extremely sparse bacterial populations may develop with less disturbance of their species composition, at least for some time, in samples with delayed nutrient addition than in samples enriched at once, thereby reducing the probability of some members of a population being out-grown by others. As a matter of fact, in several cases different bacteriophages were found with the same bacterial host from the preincubated sub-samples on the one hand and the related Sub-sample 1 on the other. Furthermore, with 56 hosts bacteriophages were found only in preparations made from Sub-samples 2 and/or 3 , and with 27 additional bacterial hosts, phages were detected from more preparations produced from these sub-samples than from Sub-sample 1. Finally, with only 34 out of 213 isolated host bacteria, bacteriophages were detected only from Sub-sample 1. Nevertheless, similar results might have been obtained if all 3 subsamples had been enriched with nutrients at zero time.

As can be seen from Table 3, considerable differences were observed in regard to the efficiency of the methods used for phage detection. They become more striking if the geographic origin of the seawater samples is taken into account. With 21 (=18\%) of the 115 "eastern" hosts (see above) versus 44 (= $45 \%$ ) of the 98 "western" host bacteria, bacteriophages could only be found by the more sensitive detection procedure employing the ring holders. From these observations it must be concluded that with the western seawater samples, which contained poorer bacterial populations than the eastern ones (Table 2), bacteriophages were enriched on the average to a lesser degree than with the eastern samples. Therefore, not only the use of several sub-samples but also the employment of more sensitive phage-detection procedures is more advantageous the poorer the bacterial content of the seawater investigated.

The phage-detection method employing the ring holders was originally developed for the use aboard ship where usual spot tests, e. g. the application of several drops per plate by loops, were found to be unreliable because drops would flow together before being absorbed by the agar. Since, however, the test takes more time than was available during the cruise, it was used only after return. Although time consuming, it is preferable to other methods of comparable sensitivity because it reduces the demand for equipment (such as hundreds of tubes which would require cleaning), needs only small amounts of expensive media, and, in the long run, saves time.

Acknowledgements. The author is indebted to Miss B. Lämmel and Miss H. Nattkemper for assistance during the method's development and the screening of collected material, respectively, to Mr. S. Heimberg for constructing the seawater sampler and ring holders, to Mr. J. Marschall for drawing Figure 1, and to Dr. J. W. Markham for support in linguistic matters. Special thanks are extended to Mrs. A. Heinemann for taking the pains to organize last minute arrival of indispensable 
equipment severely hampered by an abnormally harsh winter. Last but not least, the dependable help and companionship of the crew of RV "Friedrich Heincke" and the scientific staff during the cruise is cordially acknowledged.

\section{LITERATURE CITED}

Chaina, P. N., 1965. Some recent studies on marine bacteriophages. - J. gen. Microbiol. 41, Proc. 25. Hidaka, T., 1971. Isolation of marine bacteriophages from sea water. - Bull. Jap. Soc. scient. Fish. 37, 1199-1206.

Hidaka, T., 1977. Detection and isolation of marine bacteriophage systems in the southwestern part of the Pacific Ocean. - Mem. Fac. Fish., Kagoshima Univ. 26, 55-62.

Johnson, P. W. \& Sieburth, J. McN., 1978. Morphology of non-cultured bacterioplankton from estuarine, shelf and open ocean waters. - Abstr. a. Meet. Am. Soc. Microbiol. N 95, 178.

Spencer, R., 1955. A marine bacteriophage. - Nature, Lond. 175, 690.

Spencer, R., 1960. Indigenous marine bacteriophages. - J. Bact. 79, 614.

ZoBell, C. E., 1946. Marine microbiology. Chronica Botanica Comp., Waltham, Mass., 240 pp. 